\title{
Forage production of elephant grass under intermittent stocking
}

\author{
Carla Silva Chaves ${ }^{(1)}$, Carlos Augusto de Miranda Gomide(2), Karina Guimarães Ribeiro(1), \\ Domingos Sávio Campos Paciullo(2), Francisco José da Silva Ledo(2), \\ Igor de Almeida Costa ${ }^{(2)}$ and Ludmila Lacerda Campana ${ }^{(3)}$
}

\begin{abstract}
(1)Universidade Federal dos Vales do Jequitinhonha e Mucuri, Rodovia MG 367, no 5.000, Alto da Jacuba, CEP $39100-00$ Diamantina, MG, Brazil. E-mail: carlazootecnia@gmail.com, karina_ufvjm@yahoo.com.br (2)Embrapa Gado de Leite, Rua Eugênio do Nascimento, no 610, CEP 36038-330 Juiz de Fora, MG, Brazil. E-mail: carlos.gomide@embrapa.br, domingos.paciullo@embrapa.br, francisco.ledo@embrapa.br, igoralmeida.costa@gmail.com ${ }^{(3)}$ Universidade Federal Rural do Rio de Janeiro, BR 465, Km 7, CEP 23890-000 Seropédica, RJ, Brazil. E-mail: ludmila_llc@hotmail.com
\end{abstract}

\begin{abstract}
The objective of this work was to evaluate the dry matter production of elephant grass (Pennisetum purpureum) genotypes, managed under intermittent stocking. A completely randomized design was used, with two genotypes and three replicates. The treatments consisted of factorial combinations $(2 \times 2 \times 2)$ of genotypes ('BRS Kurumi' and the clone CNPGL 00-1-3), two light interception levels (LI) at the onset of grazing (90 and 95\%), and two post-grazing canopy heights $(30$ and $50 \mathrm{~cm}$ ). A total of 24 Holstein $x$ Zebu crossbred heifers were used. The stocking density varied in order to finish the grazing periods in two days. The interval between the defoliation, based on $95 \% \mathrm{LI}$, resulted in a higher leaf mass per grazing cycle. The post-grazing height of $30 \mathrm{~cm}$ did not affect the number of grazing cycles but provided a greater herbage accumulation rate. The cultivar BRS Kurumi has higher pasture growth, lower rest period, and greater number of grazing cycles, which results in increased forage production in the growing season.
\end{abstract}

Index terms: Pennisetum purpureum, canopy structure, grazing efficiency, leaf dry mass, rotational grazing, rest period.

\section{Produção de forragem de capim-elefante sob lotação intermitente}

Resumo - O objetivo deste trabalho foi avaliar a produção de matéria seca de genótipos de capim-elefante (Pennisetum purpureum) manejado sob lotação intermitente. Utilizou-se o delineamento inteiramente casualizado, com dois genótipos e três repetições. Os tratamentos consistiram da combinação fatorial $(2 \times 2 \times 2)$ de genótipos ('BRS Kurumi' e o clone CNPGL 00-1-3), dois níveis de interceptação luminosas (IL) por ocasião da entrada dos animais nos piquetes (90 e 95\%) e duas alturas pós-pastejo do dossel (30 e $50 \mathrm{~cm}$ ). Foram usadas 24 novilhas mestiças Holandês x Zebu. A densidade de lotação variou para que se finalizasse os períodos de pastejo em dois dias. O intervalo entre desfolhações com $95 \%$ de IL resultou em maior massa foliar por ciclo de pastejo. A altura pós-patejo de $30 \mathrm{~cm}$ não afetou o número de ciclos de pastejo, mas proporcionou maior taxa de acúmulo de forragem. A cultivar BRS Kurumi apresenta maior crescimento do pasto, menor intervalo entre pastejos e maior número de ciclos de pastejo, o que resulta em maior produção de forragem na estação de crescimento

Termos para indexação: Pennisetum purpureum, estrutura de dossel, eficiência de pastejo, matéria seca foliar, pastejo rotacionado, período de descanso.

\section{Introduction}

Elephant grass (Pennisetum purpureum Schumach.) has one of the highest production potentials among tropical forages used in intensive grazing, both in terms of forage production and animal performance (Carvalho et al., 2005; Lima et al., 2007). However, problems related to management have hampered its adoption by farmers. One difficulty is to maintain a proper vegetation structure due to its rapid stem elongation, which results in decreasing leaf/stem ratio, grazing efficiency, and forage nutritive value (Carvalho et al., 2005). Furthermore, the rapid increase in residual plant height requires frequent mowing, which enhances production costs. Therefore, short forage stature may allow higher grazing efficiency.

Grazing frequency and defoliation intensity affect canopy structure (Carnevalli et al., 2006; Barbosa et al., 2007; Difante et al., 2010). Barbosa et al. (2007) found higher accumulation rates of Panicum maximum, cultivar Tanzânia, subjected to high 
grazing frequencies (90-95\% of light interception) and intensities (50-25 cm post-grazing height). These authors also observed that pastures grazed to $50 \mathrm{~cm}$ residue produced, in average, $1,000 \mathrm{~kg} \mathrm{ha}^{-1}$ more dry matter than those grazed to $25 \mathrm{~cm}$ residue, with an average of 5,810 and $4,890 \mathrm{~kg} \mathrm{ha}^{-1}$ of dry matter, respectively.

Trindade et al. (2007), while studying Urochloa brizantha, cultivar Marandu, reported that the combination of $95 \%$ of light interception for regrowth interruption, associated with post-grazing height of $15 \mathrm{~cm}$, provided greater proportion of leaves in the forage. For elephant grass, several studies have evaluated forage production and canopy structure (Deresz, 2001; Paciullo et al., 2003; Carvalho et al., 2005; Lima et al., 2007), but those involving management strategies based on morphological criteria for defining the defoliation interval are still incipient (Gomide et al., 2011b). Moreover, knowledge of the response of new forage accesses to variation in management represents a breakthrough in the development and future adoption of cultivars.

The objective of this work was to evaluate the dry matter production of elephant grass (Pennisetum purpureum) genotypes, managed under intermittent stocking.

\section{Materials and Methods}

The experiment was carried out at the experimental farm of Embrapa Gado de Leite, located in Coronel Pacheco, MG, Brazil $\left(21^{\circ} 33^{\prime} \mathrm{S}\right.$ and $43^{\circ} 16^{\prime} \mathrm{W}$, at $435 \mathrm{~m}$ altitud), from December 2009 to April 2010. The climate, according to Köppen classification, is Cwa (mesothermal), with a tropical rainy summer and a dry winter from June to September (Peel et al., 2007).

The soil of the experimental area is classified as a Typic Udifluvent (Neossolo Flúvico distrófico, in the Brazilian classification - Santos et al., 2006), with the following chemical characteristics: $\mathrm{pH}\left(\mathrm{H}_{2} \mathrm{O}\right)$ 5.8; $10.5 \mathrm{mg} \mathrm{dm}^{-3} \mathrm{P} ; 77 \mathrm{mg} \mathrm{dm}^{-3} \mathrm{~K} ; 2.3 \mathrm{cmol}_{\mathrm{c}} \mathrm{dm}^{-3} \mathrm{Ca}$; $1.0 \mathrm{cmol}_{\mathrm{c}} \mathrm{dm}^{-3} \mathrm{Mg} ; 0.0 \mathrm{cmol}_{\mathrm{c}} \mathrm{dm}^{-3} \mathrm{Al} ; 3.50 \mathrm{cmol}_{\mathrm{c}} \mathrm{dm}^{-3}$ $\mathrm{H}+\mathrm{Al}$; sum of bases of $3.50 \mathrm{cmol}_{\mathrm{c}} \mathrm{dm}^{-3}$; cation exchange capacity of $6.21 \mathrm{cmol}_{\mathrm{c}} \mathrm{dm}^{-3}$; and soil base saturation (V\%) of $45 \%$.

Due to the values found in the soil analysis, liming was not performed prior to planting. Only phosphate was applied at pasture establishment, placed in the furrow at an equivalent of $100 \mathrm{~kg} \mathrm{ha} \mathrm{h}^{-1} \mathrm{P}_{2} \mathrm{O}_{5}$. N-P-K
(20-05-20) maintenance fertilization was performed during the rainy season, after each grazing, at equivalents of $50 \mathrm{~kg} \mathrm{ha} \mathrm{N}^{-1} \mathrm{~N}$ and $\mathrm{K}_{2} \mathrm{O}$, and $12.5 \mathrm{~kg} \mathrm{ha}^{-1}$ $\mathrm{P}_{2} \mathrm{O}_{5}$.

Pasture was established at the beginning of the rainy season of 2008 (September-October) by planting mature culms, with $80 \mathrm{~cm}$ spacing between rows. During the first year, the pasture was managed under intermittent stocking, with grazing periods of two days and grazing interval of 28 days. In December 2009, a pre-experimental grazing period was performed in order to adjust the swards according to the treatments.

Treatments consisted of a factorial combination ( $2 \times 2 \times 2)$ of two genotypes (cultivar BRS Kurumi, a dwarf grass; and clone CNPGL 00-1-3, a medium-sized grass), two light interceptions levels at the onset of grazing (90 and 95\%), and two post-grazing canopy heights (30 and $50 \mathrm{~cm}$ ), arranged in a completely randomized design, with three replicates.

It was used 24 Holstein x Zebu crossbred heifers, weighing $190 \mathrm{~kg}$. The number of animals per paddock, in order to achieve the desired post-grazing canopy height, varied from three to four heifers. The "mob grazing" technique was used to simulate the condition of rotational grazing. The experimental units (paddocks) had dimensions of $15 \times 20 \mathrm{~m}$, and the number of animals was adjusted to achieve the predetermined residue heights, considering two days of occupancy per paddock. The pre-grazing forage mass estimate was used to define the number of animals that would be placed in each paddock. After grazing on the experimental plots, the animals were maintained on another elephant grass pasture until the subsequent grazing cycle. In each grazing cycle, the order of the grazing paddocks in each treatment followed the sequence of the replicates.

The group of animals used was as uniform as possible regarding age, body weight, and score. Despite this, in each grazing cycle, the group of animals for each treatment was randomly selected to avoid possible interferences due to the inherent differences in animals.

During the grazing period, canopy height was measured to determine the amount of material removed from pasture, observing the pre-established height of the residue. The measurements were made using a ruler graduated in centimeters, collecting 20 random readings in each paddock. These canopy measurements were also performed before the animals entered the 
paddock, in order to characterize the pasture at the end of the rest period (pre-grazing).

Evaluations of the light interception (LI) levels by the canopy were performed weekly, at the removal of the animals from the paddock and during the rest period, using a canopy analyzer equipment, Accupar LP 80, (Decagon Devices, Pullman, WA, USA), with ten random readings per paddock. The dates of the entry and exit of the animals in each paddock were recorded to calculate the rest periods (days) and number of grazing cycles.

Before grazing onset, two samples of the forage mass close to the ground were harvested using a rectangular $1.0 \times 0.5 \mathrm{~m}$ frame. The sampling sites represented the average condition of the pasture in terms of vegetation height and cover. The samples were subsampled, separated into leaf, stem (culm + leaf sheath) and dead material, and dried in a forced-circulation oven at $55^{\circ} \mathrm{C}$, for 72 hours to determine total dry matter mass. Forage accumulation rate (FAR) was estimated for each grazing cycle in each treatment through the difference between pre-grazing forage mass and residual forage mass in the previous grazing cycle, divided by the number of days necessary for the recovery of the pasture (rest period).

Based on the values of total forage mass (TFM) in the pre- and post-grazed pasture, the forage-use efficiency (FUE) was estimated using the formula: $\mathrm{FUE}=\left\{\left[\left(\mathrm{TFM}_{\mathrm{Pre}}-\mathrm{TFM}_{\text {Post }}\right)-\right.\right.$ Losses $\left.] \times 100\right\} / \mathrm{TFM}_{\text {Pre }}$.

Forage loss was estimated based on the forage deposited on the ground during the grazing period, according to Carnevalli et al. (2006), considering the samples from two $1.0 \mathrm{x} 0.50 \mathrm{~m}$ rectangular frames per paddock. Sampling points were defined prior to grazing, by choosing sites that represented the average condition of the pasture; all of the plant material lying on the ground (stems and fallen green leaves, even if still attached to the plants) was collected. This material was processed using the same methodology described for forage samples collected pre- and post-grazing.

The results obtained for the structural and productive traits of the pasture were subjected to analysis of variance, and treatment means were compared by the Tukey test, at $10 \%$ probability. The values were expressed as the average of grazing cycles during the rainy season. The entire data set was tested to ensure that the basic prerogatives of the analysis of variance were met. All the evaluated factors and their interactions were considered as a fixed effect. These procedures were performed using the statistical package Sisvar.

\section{Results and Discussion}

A significant interaction was observed between treatments of light interception level and post-grazing height for total forage mass (Table 1). Under 90\% LI, forage mass did not vary between residue heights, whereas under 95\% LI, greater forage mass was observed with $50-\mathrm{cm}$ post-grazing height. Carnevalli et al. (2006) and Barbosa et al. (2007), however, reported higher production of forage mass with the association of lower residue $(30 \mathrm{~cm})$ and $95 \%$ light interception.

Increasing light interception levels only affected forage mass when associated with residual height of $50 \mathrm{~cm}$ (Table 1), most likely due to an increase in stem elongation. Stem elongation is usually associated with the shading level to which the plants are subjected. According to Parsons \& Penning (1988), the average rate of grass growth is maximized at $95 \% \mathrm{LI}$, and, therefore, this criterion has been suggested to control stem elongation in tropical grasses (Da Silva \& Nascimento Júnior, 2007). However, in grasses with early stem elongation, such as elephant grass, stem elongation seems to start even in the absence of light competition. In this sense, Carvalho et al. (2007) observed a high stem elongation in elephant grass cultivar Napier with light interception levels much lower than $95 \%$.

The amount of forage mass produced was similar to that obtained for elephant grass cultivar Napier, managed with different residue height and rest periods of 24 or 30 days (Deresz et al., 2001; Carvalho et al., 2005).

The post-grazing residue had no effect on the pre-grazing green forage mass; however, it was observed interaction between genotype and LI (Table 2). For the

Table 1. Total forage mass averages $\left(\mathrm{kg} \mathrm{ha}^{-1}\right.$ per cycle) of elephant grass pasture according to light interception and residual height $t^{(1)}$.

\begin{tabular}{|c|c|c|c|}
\hline \multirow{2}{*}{$\begin{array}{l}\text { Light interception } \\
(\%)\end{array}$} & \multicolumn{2}{|c|}{ Residual height (cm) } & \multirow{2}{*}{$\begin{array}{l}\mathrm{CV} \\
(\%)\end{array}$} \\
\hline & 30 & 50 & \\
\hline 90 & $7,475 \mathrm{aA}$ & $7,447 \mathrm{aB}$ & \multirow{2}{*}{21.9} \\
\hline 95 & $7,450 \mathrm{bA}$ & $10,023 \mathrm{aA}$ & \\
\hline
\end{tabular}


cultivar BRS Kurumi, higher green forage mass was found under 95\% LI, whereas clone CNPGL 00-1-3 showed no difference in this variable as LI varied.

When managed under 90\% LI, the clone CNPGL 00-1-3 had higher green forage mass than cultivar Kurumi, but the genotypes did not differ under $95 \%$ LI (Table 2). The smaller production of green forage mass by the cultivar BRS Kurumi was offset by its lower rest period (Table 3), which confers a higher number of grazing cycles (Table 4) and resulted in higher forage production of this cultivar during the rainy season.

Gomide et al. (2007), working with different rest periods, based on the number of green leaves per tiller in Mombaça grass, also observed that the greater number of cycles with shorter rest periods (appearance of 2.5 leaves per tiller) offsets the lower production of pre-grazing forage mass. Furthermore, the authors reported higher forage accumulation rates and a better leaf/stem ratio for this shorter rest period.

Only genotype had influence on the number of grazing cycles. Carnevalli et al. (2006) reported that this variable was not affected by the residual height of Mombaça grass, but it was higher at 95\% LI than at $100 \%$.

Table 2. Pre-grazing green forage mass averages $\left(\mathrm{kg} \mathrm{ha}^{-1} \mathrm{per}\right.$ cycle) of elephant grass pasture according to genotypes and light interception levels ${ }^{(1)}$.

\begin{tabular}{|c|c|c|c|}
\hline \multirow[t]{2}{*}{ Genotype } & \multicolumn{2}{|c|}{ Light interception (\%) } & \multirow{2}{*}{$\begin{array}{l}\mathrm{CV} \\
(\%)\end{array}$} \\
\hline & 90 & 95 & \\
\hline BRS Kurumi & $5,762 \mathrm{bB}$ & $8,158 \mathrm{aA}$ & \multirow{2}{*}{20.4} \\
\hline CNPGL 00-1-3 & $8,016 \mathrm{aA}$ & $7,962 \mathrm{aA}$ & \\
\hline
\end{tabular}

${ }^{(1)}$ Means followed by equal letters, lowercase in the rows and uppercase in columns, do not differ by the Tukey test, at $10 \%$ probability.

Table 3. Rest period (days) for the two elephant grass genotypes according to the light interception and rest period interaction ${ }^{(1)}$.

\begin{tabular}{lccc}
\hline Residue $(\mathrm{cm})$ & \multicolumn{3}{c}{ Light interception (\%) } \\
\cline { 2 - 4 } & \multicolumn{3}{c}{90} \\
\hline \multirow{3}{*}{30} & $21.3 \mathrm{aA}$ & BRS Kurumi \\
50 & $17.3 \mathrm{bB}$ & $24.5 \mathrm{aA}$ \\
\hline \multicolumn{3}{c}{ CNPGL 00-1-3 } \\
30 & $52.5 \mathrm{bA}$ & & $59.4 \mathrm{aA}$ \\
50 & $43.3 \mathrm{aB}$ & & $45.0 \mathrm{aB}$ \\
\hline $\mathrm{CV}(\%)$ & \multicolumn{3}{c}{11.5} \\
\hline
\end{tabular}

${ }^{(1)}$ Means followed by equal letters, lowercase in the rows and uppercase in columns, do not differ by the Tukey test, at $10 \%$ probability.
A rapid recovery of the pasture after defoliation avoids the appearance of invasive plants and increases forage production throughout the growing season (Gomide \& Paciullo, 2012). In addition, a longer rest period may influence the canopy structure and forage nutritional value, since it enables a higher accumulation of stem and dead material (Da Silva \& Nascimento Júnior, 2007). The cultivar BRS Kurumi had a shorter rest period (22.5 days) than CNPGL 00-1-3 (50 days). Indeed, when studying morphogenesis, Gomide et al. (2011b) found high rates of elongation and leaf appearance for the cultivar BRS Kurumi after defoliation, in summer. This favors a rapid canopy closure and, consequently, a rapid recovery (range of LI) for the next grazing period. The effects of the morphogenetic and structural characteristics of the canopy were described by Chapman \& Lemaire (1993) for temperate grasses and confirmed in tropical grasses (Gomide et al., 2006).

The genotypes and the residual heights did not cause differences as to pre-grazing leaf mass (Table 3). However, greater leaf mass was found with $95 \% \mathrm{LI}$. The lower leaf mass under $90 \% \mathrm{LI}$ can be attributed to growth limitations. In this sense, Parsons et al. (1983) reported that net forage production increases until the death of older leaves is intensified, which normally coincide with the level of $95 \%$ LI. It should be noted that the appropriate contribution of leaves to forage mass, comprising $50 \%$ of the forage, revealed a good adaptation of these genotypes to the management under rotational stocking.

Table 4. Pre-grazing leaf mass, forage accumulation rate, and number of grazing cycles according to elephant grass genotypes, light interception levels, and residual heights ${ }^{(1)}$.

\begin{tabular}{|c|c|c|c|}
\hline Variable & $\begin{array}{c}\text { Leaf mass } \\
\left(\mathrm{kg} \mathrm{ha}^{-1} \text { per cycle }\right)\end{array}$ & $\begin{array}{l}\text { Accumulation rate } \\
\left(\mathrm{kg} \mathrm{ha}^{-1} \text { per day }\right)\end{array}$ & $\begin{array}{l}\text { Grazing } \\
\text { cycles }^{(2)}\end{array}$ \\
\hline \multicolumn{4}{|l|}{ Genotype } \\
\hline BRS Kurumi & $3,438 \mathrm{a}$ & $177 \mathrm{a}$ & $6 a$ \\
\hline CNPGL 00-1-3 & $3,651 \mathrm{a}$ & $114 \mathrm{~b}$ & $3 b$ \\
\hline \multicolumn{4}{|c|}{ Light interception (\%) } \\
\hline 90 & $3,159 b$ & $120 \mathrm{~b}$ & $4 a$ \\
\hline 95 & $3,929 \mathrm{a}$ & $171 \mathrm{a}$ & $4 a$ \\
\hline \multicolumn{4}{|l|}{ Residue (cm) } \\
\hline 30 & $3,582 \mathrm{a}$ & $157 \mathrm{a}$ & $4 a$ \\
\hline 50 & $3,507 \mathrm{a}$ & $134 \mathrm{~b}$ & $4 \mathrm{a}$ \\
\hline $\mathrm{CV}(\%)$ & 21.3 & 46.6 & 15.4 \\
\hline
\end{tabular}

Pesq. agropec. bras., Brasília, v.48, n.2, p.234-240, fev. 2013 DOI: 10.1590/S0100-204X2013000200015 
Gomide et al. (2011a) observed higher leaf percentage $(82 \%)$ in pre-grazing forage mass.

The average forage accumulation rate for the cultivar BRS Kurumi was more than $60 \mathrm{~kg}$ of dry matter per day, higher than the one found for the clone CNPGL 00-1-3, representing a significantly higher forage production during the rainy season (Table 3 ). Increasing light interception from 90 to $95 \%$ also increased the accumulation rates. This result is in agreement with several studies, which show higher average growth rate of the pasture when the incident light interception is around 95\% (Mello \& Pedreira, 2004; Cândido et al., 2005; Carnevalli et al., 2006; Barbosa et al., 2007; Gomide et al., 2007).

The lower post-grazing residue $(30 \mathrm{~cm})$ provided a greater forage accumulation rate (Table 3 ). In this regard, Korte et al. (1982) demonstrated that light and frequent grazing reduce forage accumulation in ryegrass-dominant pasture, mainly due to increased respiratory demands for higher residues.

Significant interaction was observed between light interception level and residual height as to the rest periods, in both genotypes (Table 4). In general, the higher residue amount the lowest rest period, i.e., the time necessary to achieve the condition of light interception required for the next grazing. The cultivar BRS Kurumi was an exception, since no difference was observed between the residues of 30 and $50 \mathrm{~cm}$, at $95 \%$ LI. This can be explained by changes in canopy structure attributed to stem elongation (Gomide et al., 2007) and leaf angle (Mello \& Pedreira, 2004) in response to different combinations of frequency and intensity of grazing, altering light penetration in the canopy and, consequently, light interception.

For the clone CNPGL 00-1-3, a clear effect of the residual height was observed in the rest period. In both light interception levels, a lower rest period was found with the higher residue $(50 \mathrm{~cm})$. This finding is supported by the literature, with shorter intervals at lower grazing intensities (Korte et al., 1982; Fulkerson \& Slack, 1995; Barbosa et al., 2007). This response is associated with the higher height of the genotype CNPGL 00-1-3, which was reflected in a greater canopy height. Therefore, the use of $50 \mathrm{~cm}$ residue for this genotype favors its fastest recovery. Likewise, under the residue of $50 \mathrm{~cm}$ no difference was observed in the rest period between 90 and $95 \%$ IL, reinforcing the idea that this residue is suitable for that genotype.
By analogy, the smallest variation in rest periods observed for the cultivar BRS Kurumi, under different combinations of frequency and intensity of grazing, suggests easier management or greater versatility.

The genotypes differed as to pre-grazing canopy heights, with an average height of $75 \mathrm{~cm}$ for the cultivar BRS Kurumi and of $127 \mathrm{~cm}$ for the clone CNPGL 00-1-3. A significant interaction between LI and residual height was also evident for this variable (Table 5). No difference in pre-grazing canopy height between residues of 30 and $50 \mathrm{~cm}$ was observed under 90\% LI. However, under 95\% LI, the residual height of $50 \mathrm{~cm}$ increased the pre-grazing canopy height. This result corroborates the findings of Barbosa et al. (2007) and Gomide \& Paciullo (2012), who reported that the intensity and frequency of grazing are the two management factors that influence the structural and productive characteristics of tropical pasture grasses. Based on the recommendation of $95 \%$ LI for the management of tropical grasses under rotational stocking (Da Silva \& Nascimento Júnior, 2007), these results indicate a first guideline for the management of these genotypes: a pre-grazing height of $75-80 \mathrm{~cm}$ for the cultivar BRS Kurumi and of $100 \mathrm{~cm}$ for the clone CNPGL 00-1-3.

The residual forage mass varied according to the interaction between genotypes and post-grazing heights (Table 5). For the cultivar BRS Kurumi, taller residues resulted in a doubled residual mass, an expected result because higher residual mass is associated with taller plants (Mello \& Pedreira, 2004). Another factor that probably contributes to this effect is the significant shoot elongation, a consequence of a higher residue

Table 5. Pre-grazing canopy height according to light interception and residual height, and post-grazing green forage mass according to genotype and residual height of elephant grass genotypes ${ }^{(1)}$.

\begin{tabular}{lcc}
\hline Variable & \multicolumn{2}{c}{ Residual height $(\mathrm{cm})$} \\
\cline { 2 - 3 } & \multicolumn{2}{c}{50} \\
\hline Light interception (\%) & \multicolumn{2}{c}{ Pre-grazing height $(\mathrm{cm})$} \\
90 & $98.7 \mathrm{aA}$ & $96.0 \mathrm{aB}$ \\
95 & $95.5 \mathrm{bA}$ & $116.5 \mathrm{aA}$ \\
\hline CV $(\%)$ & \multicolumn{2}{c}{15.60} \\
\hline Genotype & Post-grazing green forage mass $\left(\mathrm{kg} \mathrm{ha}^{-1}\right)$ \\
BRS Kurumi & $1,917 \mathrm{bB}$ & $4,132 \mathrm{aA}$ \\
CNPGL 00-1-3 & $3,154 \mathrm{aA}$ & $3,515 \mathrm{aA}$ \\
\hline CV $(\%)$ & \multicolumn{3}{c}{31.55} \\
\hline
\end{tabular}

(1)Means followed by equal letters, lowercase in the rows and uppercase in columns, do not differ by the Tukey test, at $10 \%$ probability. 
with reduced grazing intensity. In this sense, Gomide et al. (2011b) found higher stem elongation rate at the $45 \mathrm{~cm}$ residue, when compared to the $25 \mathrm{~cm}$ residue. The genotype CNPGL 00-1-3 showed no difference as to residual mass in response to residual height, and these similar results are due to the greater difficulty in achieving the desired residue height, mainly under the lower residue, leaving around $40 \mathrm{~cm}$.

Managing pastures with a residual height of $30 \mathrm{~cm}$ provided higher residual mass for the genotype CNPGL 00-1-3 in comparison to the cultivar BRS Kurumi (Table 5). There was no difference between the genotypes with $50 \mathrm{~cm}$ residue height.

The post-grazing leaf mass, or residual leaf mass, varied between genotypes and between residual heights, but not with LI (Table 6). The cultivar BRS Kurumi had a higher residual leaf mass than CNPGL $00-1-3$, resulting in larger leaf proportion and rapid regrowth, and, therefore, in a shorter grazing interval. Residual height also influenced residual leaf mass, with higher values under lower intensity of defoliation $(50 \mathrm{~cm})$. Therefore, a higher residue after grazing should be maintained to speed the recovery of CNPGL 00-1-3 after defoliation. However, this procedure was reflected in an increased canopy height at the end of the rest period, mostly under $95 \% \mathrm{IL}$, with a consequent damage to its structure.

Neither forage-use efficiency nor forage loss was influenced by management factors and genotypes (Table 6). Cunha et al. (2007) found forage losses ranging from 3 to $5 \%$ of the total biomass, when

Table 6. Forage-use efficiency, forage loss, and post-grazing leaf mass according to elephant grass genotypes, light interception level, and residual height ${ }^{(1)}$.

\begin{tabular}{lccc}
\hline Variable & $\begin{array}{c}\text { Forage use } \\
\text { efficiency (\%) }\end{array}$ & $\begin{array}{c}\text { Forage loss } \\
\left(\mathrm{kg} \mathrm{ha}^{-1}\right)\end{array}$ & $\begin{array}{c}\text { Residue leaf mass } \\
\left(\mathrm{kg} \mathrm{ha}^{-1} \text { per cycle }\right)\end{array}$ \\
\hline Genotype & & \\
BRS Kurumi & $53.7 \mathrm{a}$ & $4.4 \mathrm{a}$ & $745.5 \mathrm{a}$ \\
CNPGL 00-1-3 & $57.6 \mathrm{a}$ & $4.6 \mathrm{a}$ & $260.9 \mathrm{~b}$ \\
\hline $\begin{array}{l}\text { Light interception (\%) } \\
90\end{array}$ & $50.4 \mathrm{a}$ & $4.7 \mathrm{a}$ & $466.4 \mathrm{a}$ \\
95 & $63.1 \mathrm{a}$ & $4.3 \mathrm{a}$ & $540.0 \mathrm{a}$ \\
\hline Residue (cm) & & \\
30 & $61.4 \mathrm{a}$ & $3.8 \mathrm{a}$ & $324.0 \mathrm{~b}$ \\
50 & $52.7 \mathrm{a}$ & $4.9 \mathrm{a}$ & $664.5 \mathrm{a}$ \\
\hline CV (\%) & 25.6 & 35.4 & 21.3 \\
\hline (1)Means followed by equal letters in columns do not differ by the Tukey test, \\
at $10 \%$ probability. (2)Forage loss, average of each two-day grazing period.
\end{tabular}

working with different elephant grass genotypes managed under a fixed rest period (44 days). In the present study, the forage loss did not reach $1 \%$ of the total biomass. This low forage loss represents a good adaptation of these genotypes to grazing and shows that the use of adapted grasses and good management strategies allows overcoming previous limitations reported for elephant grass used for grazing.

\section{Conclusions}

1. The cultivar BRS Kurumi has higher pasture growth, lower rest period, and greater number of grazing cycles, resulting in increased forage production in the growing season.

2. The use of the light interception of $90 \%$ for regrowth interruption compromises the leaf production and forage accumulation rate in elephant grass.

3 . The post-grazing canopy height of $30 \mathrm{~cm}$ provides a greater forage accumulation rate and increases the use-efficiency of the forage produced; however, for the genotype CNPGL 00-1-3 this residue delays regrowth.

\section{Acknowledgements}

To Fundação de Amparo à Pesquisa do Estado de Minas Gerais (Fapemig) and to Conselho Nacional de Desenvolvimento Científico e Tecnológico (CNPq), for financial support and grants.

\section{References}

BARBOSA, R.A.; NASCIMENTO JÚNIOR, D.; EUCLIDES, V.P.B.; SILVA, S.C. da; ZIMMER, A.H.; TORRES JÚNIOR, R.A. de A. Capim-tanzânia submetido a combinações entre intensidade e frequência de pastejo. Pesquisa Agropecuária Brasileira, v.42, p.329-340, 2007. DOI: 10.1590/S0100-204X2007000300005.

CÂNDIDO, M.J.D.; GOMIDE, C.A.M.; ALEXANDRINO, E.; GOMIDE, J.A.; PEREIRA, W.E. Morfofisiologia do dossel de Panicum maximum cv. Mombaça sob lotação intermitente com três períodos de descanso. Revista Brasileira de Zootecnia, v.34, p.406-415, 2005. DOI: 10.1590/S1516-35982005000200007.

CARNEVALLI, R.A.; DA SILVA, S.C.; BUENO, A.A.O.; UEBELE, M.C.; BUENO, F.O.; HODGSON, J.; SILVA, G.N.; MORAIS, J.P.G. Herbage production and grazing losses in Panicum maximum cv. Mombaça under four grazing managements. Tropical Grasslands, v.40, p.165-176, 2006.

CARVALHO, C.A.B. de; DERESZ, F.; ROSSIELLO, R.O.P.; PACIULLO, D.S.C. Influência de intervalos de desfolha e de alturas do resíduo pós-pastejo sobre a produção e a composição da forragem e do leite em pastagens de capim-elefante. Boletim da Indústria Animal, v.62, p.177-188, 2005. 
CARVALHO, C.A.B. de; ROSSIELO, R.O.P.; PACIULLO, D.S.C.; SBRISSIA, A.F.; DERESZ, F. Classes de perfilhos na composição do índice de área foliar em pastos de capim-elefante. Pesquisa Agropecuária Brasileira, v.42, p.557-563, 2007. DOI: 10.1590/S0100-204X2007000400014.

CHAPMAN, D.F.; LEMAIRE, G. Morphogenetic and structural determinants of regrowth after defoliation. In: INTERNATIONAL GRASSLAND CONGRESS, 17., 1993, Palmerston North. Proceedings. Palmerston North: New Zealand Society of Animal Production, 1993. p.95-104.

CUNHA, M.V. da; SANTOS, M.V.F. dos; LIRA, M. de A.; MELLO, A.C.L. de; FREITAS, E.V.; APOLINÁRIO, V.X. de O. Genótipos de capim-elefante sob pastejo no período de seca na Zona da Mata de Pernambuco: fatores relacionados à eficiência de pastejo. Revista Brasileira de Zootecnia, v.36, p.291-300, 2007. DOI: $10.1590 /$ S1516-35982007000200004.

DA SILVA, S.C.; NASCIMENTO JÚNIOR, D. do. Avanços na pesquisa com plantas forrageiras tropicais em pastagens: características morfofisiológicas e manejo do pastejo. Revista Brasileira de Zootecnia, v.36, p.121-138, 2007. DOI: 10.1590/ S1516-35982007001000014.

DERESZ, F. Influência do período de descanso da pastagem de capim-elefante na produção de leite de vacas mestiças Holandês-Zebu. Revista Brasileira de Zootecnia, v.30, p.461-469, 2001. DOI: 10.1590/S1516-35982001000200024.

DIFANTE, G. dos S.; EUCLIDES, V.P. de B.; NASCIMENTO JÚNIOR, D. do; DA SILVA, S.C.; BARBOSA, R.A.; TORRES JÚNIOR, R.A. de A. Desempenho e conversão alimentar de novilhos de corte em capim-tanzânia submetido a duas intensidades de pastejo sob lotação rotativa. Revista Brasileira de Zootecnia, v.39, p.33-41, 2010. DOI: 10.1590/ S1516-35982010000100005.

FULKERSON, W.J.; SLACK, K. Leaf number as a criterion for determining defoliation time for Lolium perenne: 2. Effect of defoliation frequency and height. Grass and Forage Science, v.50, p.16-20, 1995. DOI: 10.1111/j.1365-2494.1995.tb02289.x.

GOMIDE, C.A. de M.; GOMIDE, J.A.; ALEXANDRINO, E. Características estruturais e produção de forragem em pastos de capim-mombaça submetidos a períodos de descanso. Pesquisa Agropecuária Brasileira, v.42, p.1487-1494, 2007. DOI: 10.1590/ S0100-204X2007001000017.

GOMIDE, C.A. de M.; GOMIDE, J.A.; PACIULLO, D.S.C. Morfogênese como ferramenta para o manejo de pastagens. Revista Brasileira de Zootecnia, v.35, p.554-579, 2006. Suplemento especial.

GOMIDE, C.A. de M.; PACIULLO, D.S.C. Estratégias para o manejo do capim-elefante sob pastejo. In: SIMPÓSIO SOBRE MANEJO ESTRATÉGICO DA PASTAGEM, 6., 2012, Viçosa. Anais. Viçosa: UFV, 2012. p.91-128.

GOMIDE, C.A. de M.; PACIULLO, D.S.C.; CASTRO, C.R.T. de; LÉDO, F.J. da S.; MORENZ, M.J.F. Produção de forragem e valor nutritivo de clones de capim-elefante anão sob estratégias de desfolha intermitente. Juiz de Fora: Embrapa Gado de Leite, 2011a. 23p. (Embrapa Gado de Leite. Boletim de pesquisa e desenvolvimento, 31).

GOMIDE, C.A. de M.; PACIULLO, D.S.C.; COSTA, I. de A.; LIMA, A.M.; CASTRO, C.R.T. de; LÉDO, F.J. da S. Morphogenesis of dwarf elephant clones in response to intensity and frequency of defoliation in dry and rainy seasons. Revista Brasileira de Zootecnia, v.40, p.1445-1451, 2011b. DOI: 10.1590/ S1516-35982011000700007.

KORTE, C.J.; WATKIN, B.R.; HARRIS, W. Use of residual leaf area index and light interception as criteria for spring grazing management of ryegrass-dominant pasture. New Zealand of Agricultural Research, v.25, p.309-310, 1982. DOI: 10.1080/00288233.1982.10417892.

LIMA, E. da S.; SILVA, J.F.C. da; VÁSQUEZ, H.M.; ARAÚJO, S.A. de C.; LISTA, F.N.; COSTA, D.P.B. da. Produção de matéria seca e proteína bruta e relação folha/colmo de genótipos de capim-elefante aos 56 dias de rebrota. Revista Brasileira de Zootecnia, v.36, p.1518-1523, 2007. DOI: 10.1590/ S1516-35982007000700009.

MELLO, A.C.L. de; PEDREIRA, C.G.S. Respostas morfológicas do capim-Tanzânia (Panicum maximum Jacq. cv. Tanzânia-1) irrigado à intensidade de desfolha sob lotação rotacionada. Revista Brasileira de Zootecnia, v.33, p.282-289, 2004. DOI: 10.1590/ S1516-35982004000200003.

PACIULLO, D.S.C.; DERESZ, F.; AROEIRA, L.J.M.; MORENZ, M.J.F.; VERNEQUE, R. da S. Morfogênese e acúmulo de biomassa foliar em pastagem. Pesquisa Agropecuária Brasileira, v.38, p.881-887, 2003. DOI: 10.1590/S0100-204X2003000700013.

PARSONS, A.J.; LEAFE, E.L.; COLLETT, B.; STILES, W. The physiology of grass production under grazing. I. Characteristics of leaf and canopy photosynthesis of continuously grazed swards. Journal of Applied Ecology, v.20, p.117-126, 1983. DOI: $10.2307 / 2403380$.

PARSONS, A.J.; PENNING, P.D. The effect of the duration of regrowth on photosynthesis, leaf death and average rate of growth in a rotationally grazed sward. Grass and Forage Science, v.43, p.15-27, 1988. DOI: 10.1111/j.1365-2494.1988.tb02137.x.

PEEL, M.C.; FINLAYSON, B.L.; MCMAHON, T.A. Updated world map of the Köppen-Geiger climate classification. Hydrology and Earth System Sciences, v.11, p.1633-1644, 2007. DOI: 10.5194/hess-11-1633-2007.

SANTOS, H.G. dos; JACOMINE, P.K.T.; ANJOS, L.H.C. dos; OLIVEIRA, V.A. de; OLIVEIRA, J.B. de; COELHO, M.R.; LUMBRERAS, J.F.; CUNHA, T.J.F. (Ed.). Sistema brasileiro de classificação de solos. 2.ed. Rio de janeiro: Embrapa Solos, 2006. 306p.

TRINDADE, J.K. da; DA SILVA, S.C.; SOUZA JÚNIOR, S.J. de; GIACOMINI, A.A.; ZEFERINO, C.V.; GUARDA, V. Del A.; CARVALHO, P.C. de F. Composição morfológica da forragem consumida por bovinos de corte durante o rebaixamento do capim-marandu submetido a estratégias de pastejo rotativo. Pesquisa Agropecuária Brasileira, v.42, p.883-890, 2007. DOI: 10.1590/S0100-204X2007000600016.

Received on August 16, 2012 and accepted on February 5, 2013

Pesq. agropec. bras., Brasília, v.48, n.2, p.234-240, fev. 2013

DOI: $10.1590 / \mathrm{S} 0100-204 X 2013000200015$ 